\title{
Vertical volumetric distribution of an axial fan sprayer on the Brevipalpus phoenicis control ${ }^{1}$
}

\author{
José Márcio de Souza Júnior ${ }^{2}$, Renato Adriane Alves Ruas², \\ João de Deus Godinho Júnior ${ }^{2}$, Alberto Carvalho Filho², Vinícius Ribeiro Faria ${ }^{2}$
}

\section{ABSTRACT}

Spray distribution generated by axial fan sprayer, among other factors, should be critically analyzed, in order to prevent unnecessary costs and environmental contamination. This study aimed at evaluating the effect of the vertical volumetric distribution of an axial fan sprayer on the Brevipalpus phoenicis control efficiency. First, an assay was performed to evaluate the vertical volume distribution uniformity of the sprayer, assessing different spray nozzles configurations on the spray arcs, sides of the sprayer and spray heights. Afterwards, another experiment was carried out to analyze the relationship between the distribution of the Fenpyroximate acaricide on Coffea arabica L. and the B. phoenicis control efficiency. The treatments were arranged in a $4 \times 2$ factorial +1 additional control, consisting of four spray volumes $\left(200 \mathrm{~L} \mathrm{ha}^{-1}, 400 \mathrm{~L} \mathrm{ha}^{-1}, 600 \mathrm{~L} \mathrm{ha}^{-1}\right.$ and $800 \mathrm{~L} \mathrm{ha}^{-1}$ ) and two spray nozzles configurations (1: $100 \%$ of $\mathrm{MAG}_{1.5}$ nozzles; 2 : upper extension with $5 \mathrm{MAG}_{3.0}$ nozzles, middle extension with $9 \mathrm{MAG}_{1.5}$ nozzles and lower extension with $4 \mathrm{MAG}_{3.0}$ nozzles). Configuration 2 provided the smallest coefficient of variation $(28 \%)$. Nozzle configurations had no effect on the incidence of $B$. phoenicis. The use of nozzles with different flow rates on the spraying arc improves the vertical volumetric distribution uniformity of axial fan sprayers, but does not affect the B. phoenicis control efficiency.

KEY-WORDS: Coffea arabica L.; spray nozzles; pesticide application.

\section{INTRODUCTION}

Coffee production is a very important activity for the Brazilian agribusiness, where coffee is one of the major commodities. Estimated domestic production from the 2015 harvest is $1,878 \mathrm{t}$ (31.3 million bags) of processed Arabica coffee (Conab 2015).

In order to reach high yields, it is necessary to adopt various technologies, including the application of pesticides via axial fan sprayer. The

\section{RESUMO}

Distribuição volumétrica vertical de pulverizador hidropneumático no controle de Brevipalpus phoenicis

A distribuição de calda proporcionada por pulverizadores hidropneumáticos, dentre outros fatores, deve ser analisada com critério, sob pena de elevar custos de produção e causar contaminação ambiental. Objetivou-se avaliar o efeito da distribuição volumétrica vertical de pulverizador hidropneumático na eficácia de controle de Brevipalpus phoenicis. Primeiramente, realizou-se ensaio visando a avaliar a uniformidade de distribuição volumétrica vertical do pulverizador, considerando-se diferentes configurações de pontas nos arcos de pulverização, lados e altura de pulverização. Em seguida, realizou-se outro experimento, com o intuito de analisar a relação entre a distribuição do acaricida Fenpiroximato, aplicado a lavoura de Coffea arabica L., e o controle de B. phoenicis. Os tratamentos foram dispostos em esquema fatorial $4 \times 2+1$ testemunha adicional, sendo eles: quatro volumes de calda $\left(200 \mathrm{~L} \mathrm{ha}^{-1}, 400 \mathrm{~L} \mathrm{ha}^{-1}, 600 \mathrm{~L} \mathrm{ha}^{-1}\right.$ e $800 \mathrm{~L} \mathrm{ha}^{-1}$ ) e duas configurações de pontas (1: $100 \%$ das pontas $\mathrm{MAG}_{1,5} ; 2$ : parte superior com 5 pontas $\mathrm{MAG}_{3,0}$, parte mediana com 9 pontas $\mathrm{MAG}_{1,5}$ e parte inferior com 4 pontas $\mathrm{MAG}_{3,0}$ ). A configuração 2 proporcionou o menor coeficiente de variação (28\%). As configurações de pontas não apresentaram efeito na incidência de B. phoenicis. A utilização de pontas com diferentes vazões no arco de pulverização melhora a uniformidade de distribuição volumétrica vertical dos pulverizadores hidropneumáticos, mas não influencia na eficácia de controle de $B$. phoenicis.

PALAVRAS-CHAVE: Coffea arabica L.; pontas de pulverização; aplicação de agrotóxico.

working principle of this sprayer is based on the fragmentation of pressurized liquid into droplets that are released into a high flow and velocity air stream. The high pressure air stream promotes new fragmentation, carrying the droplets to the plant canopy, even at hard-to-reach targets (Ruas et al. 2015).

However, the airflow produced by axial fan sprayers is usually distributed unevenly along the fan outlet (Rodrigues et al. 2008). This is due to the

1. Manuscript received in Mar./2016 and accepted for publication in Jun./2016 (http://dx.doi.org/10.1590/1983-40632016v4640349).

2. Universidade Federal de Viçosa, Instituto de Ciências Agrárias, Rio Paranaíba, MG, Brazil. E-mails: jose.marcio@ufv.br, renatoruas@ufv.br, joao.gj3@gmail.com,vinicius.faria@ufv.br, acarvalhofilho@ufv.br. 
clockwise spinning of the fan, resulting in a greater airflow from the right side, when compared to the left side (Herrera Prat et al. 2002). Therefore, because the airflow produced by the fan has a direct influence on spray distribution uniformity in the plant canopy (Sotolongo \& Herrera 1986), it is possible that the active principle of the applied product does not reach important targets on the plant, hampering the treatment efficacy.

Another factor that may contribute to reduce the application efficiency is the distance between the sprayer nozzle and the target (Mion et al. 2011). Due to the concavity of the spray arc and plant architecture, nozzles positioned at the extremities of the arc present a greater distance to the target. Because the droplets are carried by the airflow (Sotolongo \& Herrera 1986), as the distance between the sprayer nozzle and target increases, the droplet reaches the leaves with less energy and is therefore more subject to drift, reducing the capacity for penetration and deposition on the plant canopy.

This problem may be minimized with the use of spray nozzles that produce larger-diameter droplets at the extremities of the spray arc. These larger droplets are less subject to drift losses, which may result in increased spray deposition at the positions most distant from the spray arch (Balan et al. 2006), and consequently increased vertical distribution uniformity of the spray.

However, large droplets may present reduced product penetration capacity in the canopy (Cunha et al. 2005). This can result in reduced control efficiency of certain pests, such as the leprosis mite (Brevipalpus phoenicis), transmitter of the coffee ringspot virus (CoRSV) (Almeida et al. 2012). The control of B. phoenicis can be difficult, because it generally stays in the inner middle and inner lower portions of the coffee plant (Reis et al. 2000).

Thus, it is necessary to perform studies to clarify the relationship between the volumetric distribution dynamics provided by axial fan sprayers and efficiency of the pesticide treatments.

This study aimed at evaluating the effect of vertical volumetric distribution of an axial fan sprayer on the Brevipalpus phoenicis control efficiency.

\section{MATERIAL AND METHODS}

The experiment was divided into two parts: determination of the vertical volumetric distribution uniformity of an axial fan sprayer and analysis of the relationship between the distribution of acaricides on coffee plants and the control efficiency.

In the first part of the experiment, evaluations of the vertical volumetric distribution uniformity were performed in Rio Paranaíba (19¹3'0.90"S and $46^{\circ} 20^{\prime} 36.16^{\prime}$ 'W), Minas Gerais State, Brazil, in 2015. A completely randomized design was employed in a $3 \times 2 \times 2$ factorial arrangement, consisting of three configurations of the spray arc nozzles (configuration 1: $100 \%$ of $\mathrm{MAG}_{1.5}$ nozzles; configuration 2: lower extension with $9 \mathrm{MAG}_{1.5}$ nozzles and upper extension with $9 \mathrm{MAG}_{3.0}$ nozzles; configuration 3: upper extension with $5 \mathrm{MAG}_{3.0}$ nozzles, middle extension with $9 \mathrm{MAG}_{1.5}$ nozzles and lower extension with $4 \mathrm{MAG}_{3.0}$ nozzles), both sides of the spray extension (right and left) and two collection heights of the sprayed liquid (0-1.6 $\mathrm{m}$ and 1.6-3.2 m), with four replications, totaling 48 experimental units. The nozzles Magno Jet ${ }^{\mathbb{B}}$ (MAG) 1.5 and 3.0 have flow rates of $0.56 \mathrm{~L} \mathrm{~min}^{-1}$ and $1.13 \mathrm{~L} \mathrm{~min}^{-1}$, respectively, with a pressure of $300 \mathrm{kPa}$.

A vertical collector was constructed, consisting of four sections measuring $1 \mathrm{~m}$ long and $2 \mathrm{~m}$ wide, in order to collect the sprayed liquid at heights up to $4 \mathrm{~m}$. Each session consisted of 10 channels of galvanized steel bent into a "V" shape, spaced at $0.10 \mathrm{~m}$. The base of the test apparatus was constructed with a $2 \%$ horizontal inclination to one of the channel extremities, for fluid flow, to which silicon hoses with a diameter of $0.01 \mathrm{~m}$ were connected. The ends of these hoses were in turn placed in 2-L polyethylene bottles to collect the volume deposited in each of the channels.

A tractor sprayer (Arbus Model 2000 TP VA Jacto $^{\circledR}$, with a tank capacity of $2,000 \mathrm{~L}$ ) was used. The sprayer was equipped with a piston pump (model JP-190) rated for flow rates up to $190 \mathrm{~L} \mathrm{~min}^{-1}$ and a radial fan that generated an airflow of $19 \mathrm{~m}^{3} \mathrm{~s}^{-1}$. It has a double arch with 36 spray nozzles (18 left and 18 right) individually adjustable, thus allowing various flow configurations from the nozzles. The tractor used was a Valtra ${ }^{\circledR}$ model BF75 4 × 2 (TDA), whose power at 2,300 rpm is $53 \mathrm{~kW}$ and maximum torque at $1,400 \mathrm{rpm}$ is $260 \mathrm{~N} . \mathrm{m}$. The sprayer was regulated and calibrated by the conventional method for a water application volume of $500 \mathrm{~L} \mathrm{ha}^{-1}$.

During the treatments application, the distance between the sprayer and vertical collector was $1.9 \mathrm{~m}$ (considering spacing between rows of $3.8 \mathrm{~m}$, 
commonly adopted in the Brazilian Savannah coffee production), and the operating time was 60 seconds. The liquid volume from each of the 40 collection recipients was measured in a graduated cylinder. The average temperature during the evaluations was $20^{\circ} \mathrm{C}$, average relative humidity was $61 \%$ and average wind velocity was $5 \mathrm{~km} \mathrm{~h}^{-1}$.

The distribution profile was determined and its uniformity was estimated with the coefficient of variation $(\mathrm{CV})$ for vertical volume on the left and right sides of the sprayer, considering the sprayer height of $3.2 \mathrm{~m}$ (average height of coffee plants in the region). Data were subjected to analysis of variance and means compared by the Tukey test at $5 \%$.

Subsequently, the airflow produced by the fan acting on each spray nozzle was estimated. For this purpose, the air velocity was measured using a digital anemometer (model AD-250 Instrutherm ${ }^{\circledR}$ ) with resolution of $0.10 \mathrm{~m} \mathrm{~s}^{-1}$, positioned parallel to each point at a distance of $0.10 \mathrm{~m}$, on both sides of the fan. From the total air outlet area parallel to the extensions on the right and left sides, the area of each section was determined. This allowed to estimate the airflow on each of the 36 spray nozzles, according to the equation $q=a \times \omega$, where: $q=$ airflow $\left(\mathrm{m}^{3} \mathrm{~s}^{-1}\right) ; a=$ areas of the section at which the air velocity was measured $\left(\mathrm{m}^{2}\right)$; and $\omega=$ velocity at each point $\left(\mathrm{m} \mathrm{s}^{-1}\right)$.

The second part of the experiment, which consisted of verifying the effect of the vertical volumetric distribution of acaricide applied with the hydropneumatic sprayer on the $B$. phoenicis control efficiency, was performed on a plot with ten years old Coffea arabica L. (Catucaí Amarelo cultivar), at a farm in Carmo do Paranaíba (18 59'30"S, $46^{\circ} 19^{\prime} 01^{\prime \prime} \mathrm{W}$ and average altitude of 1,050 m), Minas Gerais State, Brazil, where the climate is defined as Cwa, according to the Köppen classification. The plot was implemented with spacing between plants and rows of $0.6 \mathrm{~m}$ and $3.8 \mathrm{~m}$, respectively. The plants had an average height of $3 \mathrm{~m}$.

The experiment was conducted in a randomized blocks design and the treatments were arranged in a $4 \times 2+1$ factorial, as it follows: four spray volumes (200 L ha-1, $400 \mathrm{~L} \mathrm{ha}^{-1}, 600 \mathrm{~L} \mathrm{ha}^{-1}$ and $800 \mathrm{~L} \mathrm{ha}^{-1}$ ) and two spray nozzle configurations on the spraying arc (configuration 1: $100 \%$ of $\mathrm{MAG}_{1.5}$ nozzles; configuration 3: upper extension with $5 \mathrm{MAG}_{30}$ nozzles, middle extension with $9 \mathrm{MAG}_{1.5}$ nozzles and lower extension with $4 \mathrm{MAG}_{3.0}$ nozzles), plus one additional control, and four replications, totaling 36 experimental units. The configurations used were those that provided the lowest coefficient of variation for the vertical volumetric distribution in the previous experiment. The control treatment had no acaricide application.

Each block was composed by four coffee rows, each with nine plots consisting of 60 plants. Plots and blocks were spaced by $30 \mathrm{~m}$, thus providing enough space for tractor gear changes, in order to alter the velocities in each treatment and minimize the possible drift effects.

The acaricide used was fenpyroximate (Ortus $50 \mathrm{SC}^{\circledR}$ ), from the chemical group of pyrazoles, at a dose of $1 \mathrm{~L} \mathrm{ha}^{-1}$ of the commercial product. This product acts by contact and ingestion. Together with the acaricide, the Master Forth ${ }^{\circledR}$ adjuvant, at a dose of $0.03 \mathrm{~L} \mathrm{ha}^{-1}$, was added to the spray, which is characterized by having the effect of a surfactant and thickener.

Spraying was carried out with the same sprayer used in the first experiment. However, it was pulled and driven by a New Holland ${ }^{\circledR}$ tractor, model TT 3880, whose power at 2,500 rpm is $44.1 \mathrm{~kW}$. The tractor had a maximum torque of $200 \mathrm{Nm}$ at 1,500 rpm. The sprayer was previously adjusted and calibrated by setting the velocity and pressure distribution for releasing the appropriate spray volume to each treatment (Table 1). During application, the average temperature was $26^{\circ} \mathrm{C}$, the average relative humidity was $59 \%$ and the average wind speed was $3 \mathrm{~km} \mathrm{~h}^{-1}$.

To assess the penetration capacity of droplets into the plant canopy, water sensitive papers were

Table 1. Pressures, velocities and gears used by the tractor-axial fan sprayer set seeking to obtain the desired spray volumes.

\begin{tabular}{ccccl}
\hline $\begin{array}{c}\text { Flow } \\
\left(\mathrm{L} \mathrm{ha}^{-1}\right)\end{array}$ & $\begin{array}{c}\text { Nozzle } \\
\text { configurations* }\end{array}$ & $\begin{array}{c}\text { Pressure } \\
(\mathrm{kPa})\end{array}$ & $\begin{array}{c}\text { Velocity } \\
\left(\mathrm{km} \mathrm{h}^{-1}\right)\end{array}$ & \multicolumn{1}{c}{ Gear } \\
\hline 200 & 1 & 310 & 11 & $2^{\text {nd }}$ simple \\
400 & 1 & 414 & 6 & $4^{\text {th }}$ reduced \\
600 & 1 & 445 & 5 & $3^{\text {rd }}$ reduced \\
800 & 1 & 379 & 3 & $2^{\text {nd }}$ reduced \\
200 & 3 & 103 & 11 & $2^{\text {nd }}$ simple \\
400 & 3 & 569 & 11 & $2^{\text {nd }}$ simple \\
600 & 3 & 379 & 6 & $4^{\text {th }}$ reduced \\
800 & 3 & 1,448 & 8 & $1^{\text {st }}$ simple \\
\hline
\end{tabular}

* Configuration 1: $100 \%$ of the MAG ${ }_{15}$ nozzles. Configuration 3: upper extension with $5 \mathrm{MAG}_{3.0}$ nozzles, middle extension with $9 \mathrm{MAG}_{1.5}$ nozzles and lower extension with $4 \mathrm{MAG}_{3.0}$ nozzles 
fixed to the orthotropic branch at three heights (bottom, middle and upper third). To control possible effects of the side of passage (right or left side of the extension) at the time of application, the application side was alternated between repetitions. Then, the papers were removed, identified and placed in properly labeled packages. In the laboratory, the papers were scanned using a calibrated scanner with resolution of $600 \mathrm{dpi}$ and images of spray stains were processed using the CIR 1.5 software (INTA 2002). The variables determined were the percent coverage (PC) $(\%)$ and density of the droplets (DD) (drops $\mathrm{cm}^{-2}$ ).

To estimate the $B$. phoenicis control efficiency, one evaluation was performed before the application of the treatments and other three evaluations were carried out after the application ( $24 \mathrm{~h}$ after application HAA, and 4 and 14 days after application - DAA). For this purpose, five plants from the central row of each plot were sampled, and eight branches were sampled from each plant: two internal median branches, two external median branches, two internal lower branches and two external lower branches (Gravena 1992). The occurrence of live adults or nymphs of B. phoenicis was verified using a magnifying glass with 40-times resolution capacity, to estimate the percentage of branches attacked.

Data were subjected to analysis of variance $(p \leq 0.05)$, and when significant, the treatment levels were compared with the Tukey test at $5 \%$. In case of significance of the quantitative variables spray volume, a regression analysis was performed.

\section{RESULTS AND DISCUSSION}

No significant difference $(\mathrm{p}>0.05)$ was verified in the average $\mathrm{CV}$ of the vertical volumetric distribution for nozzle configurations 2 and 3, on the left and right sides of the spray arc. However, for configuration 1 , the left side of the spray arc resulted in a $\mathrm{CV}$ of vertical volumetric distribution $22 \%$ smaller than the right side (Table 2). This can be attributed to the fact that the drops are carried by airflow (Sotolongo \& Herrera 1986), and the right side has a higher airflow due to the clockwise spinning direction of the fan (Herrera Prat et al. 2002 and 2013) (Figure 1).

Furthermore, the arc shape and positioning of the nozzles, in relation to the position and direction of the fan rotation, also influence the distribution of the sprayed liquid (Alvarenga et al. 2014). The

Table 2. Coefficient of variation (CV \%) of the vertical volumetric distribution provided by the right and left sides of the axial fan sprayer, when operated with different hydraulic nozzle configurations at two spraying heights.

\begin{tabular}{lccc}
\hline \multirow{2}{*}{ Side } & \multicolumn{3}{c}{ Hydraulic nozzle configuration } \\
\cline { 2 - 4 } & $1: 18 \mathrm{MAG}_{1.5}$ nozzles & $\begin{array}{c}2: 9 \mathrm{MAG}_{1.5} \text { nozzles and } \\
9 \mathrm{MAG}_{3.0} \text { nozzles }\end{array}$ & $\begin{array}{c}3: 5 \mathrm{MAG}_{3.0} \text { nozzles, } 9 \mathrm{MAG}_{1.5} \\
\text { nozzles and } 4 \mathrm{MAG}_{3.0} \text { nozzles }\end{array}$ \\
\hline Left & $38 \mathrm{bB}$ & $47 \mathrm{aA}$ & $29 \mathrm{bA}$ \\
Right & $49 \mathrm{aA}$ & $46 \mathrm{aA}$ & $26 \mathrm{bA}$ \\
\hline Height $(\mathrm{m})$ & & & \\
\hline $0-1.6$ & $33 \mathrm{bB}$ & $43 \mathrm{aB}$ & $18 \mathrm{cB}$ \\
$1.6-3.2$ & $55 \mathrm{aA}$ & $50 \mathrm{aA}$ & $37 \mathrm{bA}$ \\
\hline Means followed by the same lower-case letter in the line, or by the same uper-case letter in the column do not differ according to the Tukey test at $5 \%$
\end{tabular}

Means followed by the same lower-case letter in the line, or by the same upper-case letter in the column, do not differ according to the Tukey test at $5 \%$.
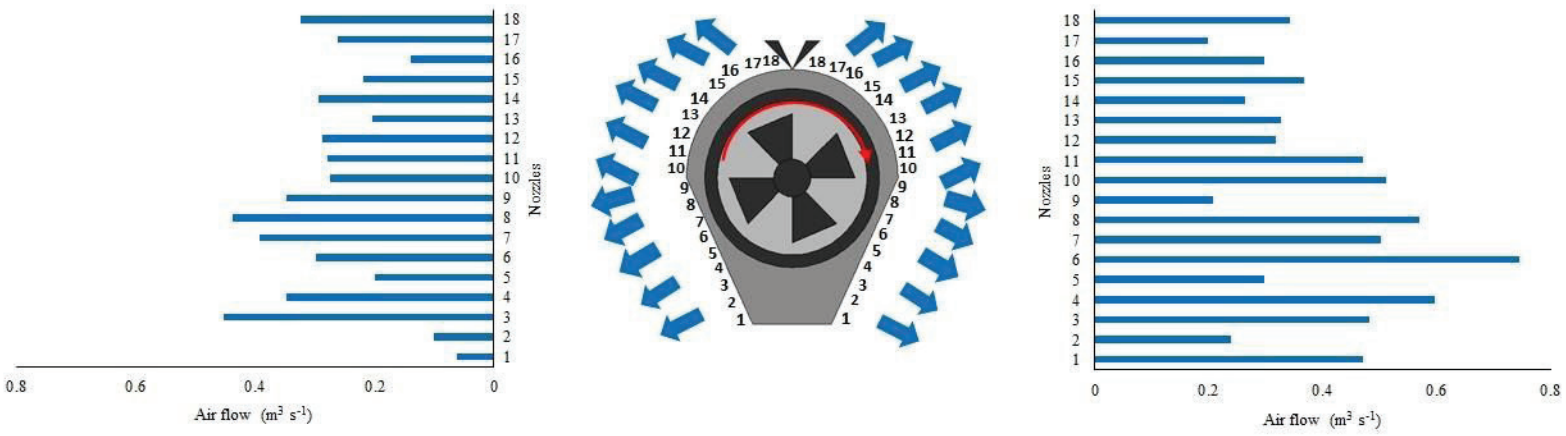

Figure 1. Distribution profile of airflow from the hydraulic nozzles of both sides of an axial fan sprayer. 
nozzles located along the lower portion of the arc are positioned at a greater distance from the fan blades, and are therefore subject to reduced airflow. Additionally, due to the air outlet curvature, the lower nozzles present a greater distance to the target and are more subject to environmental action, where the spray droplets may be carried by the wind (Alvarenga et al. 2014). This fact can be observed in the treatment in which nozzles were employed, that produced larger drops at the bottom of the arc (configuration 3), resulting in an increased distribution uniformity of $47 \%$, in relation to the right side of configuration 1 (Table 2). This may also be indicated by the CV of the vertical volumetric distribution at the average height of $0-1.6 \mathrm{~m}$, wherein configuration 3 presented CVs $58 \%$ and $45 \%$ lower than configurations 1 and 2 , respectively.

At the height of 1.6-3.2 m, the CVs of the vertical volumetric distribution of configurations 1,2 and 3 were respectively $40 \%, 14 \%$ and $51 \%$ higher, in relation to the heights of $0-1.6 \mathrm{~m}$. This fact can be attributed to the concavity of the spray arc being more pronounced at this end, resulting in a greater distance between the nozzle and the target, and therefore greater losses. Furthermore, configuration 3, at the height of 1.6-3.2 m, presented $\mathrm{CV}$ of the vertical volumetric distribution values $33 \%$ and $26 \%$ lower, in relation to configurations 1 and 2, respectively (Table 2). By having nozzles that produced larger diameter droplets at the ends of the arc, these droplets have a longer useful life and are less carried by the wind, allowing deposition of larger quantities on the targets.

For the height of 1.6-3.2 m, the left side of the sprayer extension indicated a $\mathrm{CV}$ of vertical volumetric distribution $20 \%$ greater than the height of 0-1.6 m, what can be attributed to the upward direction of the airflow (Alvarenga et al. 2014) (Table 3). Airflow increases from the lower end to the upper section of the arc, resulting in deposition of higher spray volumes at the height of 1.6-3.2 m (Figures 1 and 2).

When comparing the two sides of the spray arc, it was observed that, for both heights, the right side resulted in the highest $\mathrm{CV}$ of the vertical volumetric distribution (Table 3). This may be associated with the

(a)
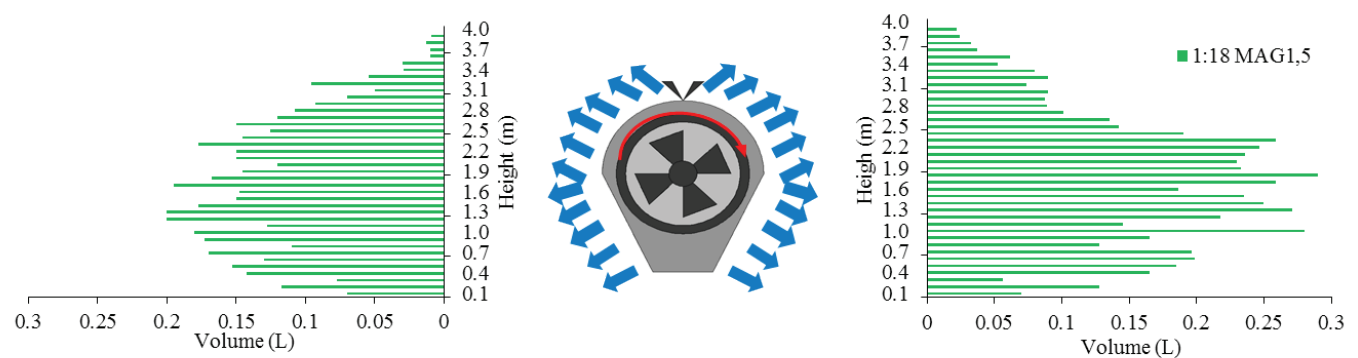

(b)
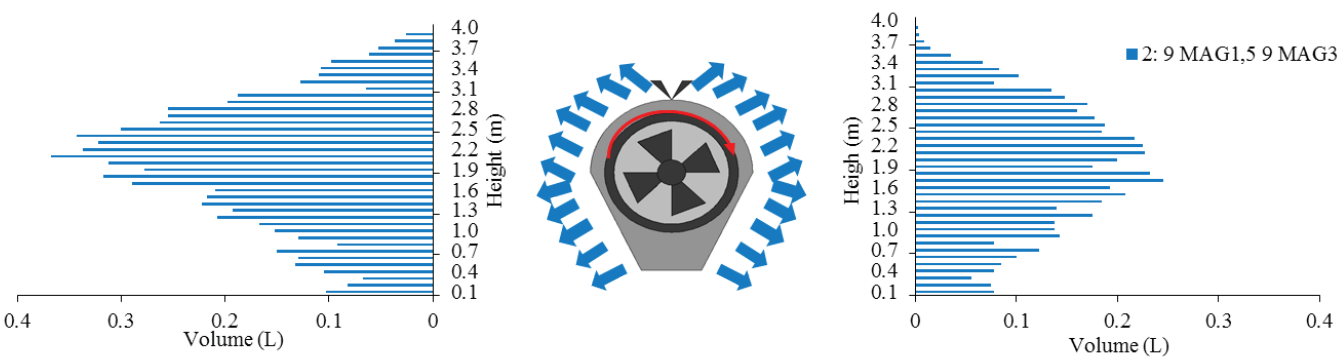

(c)
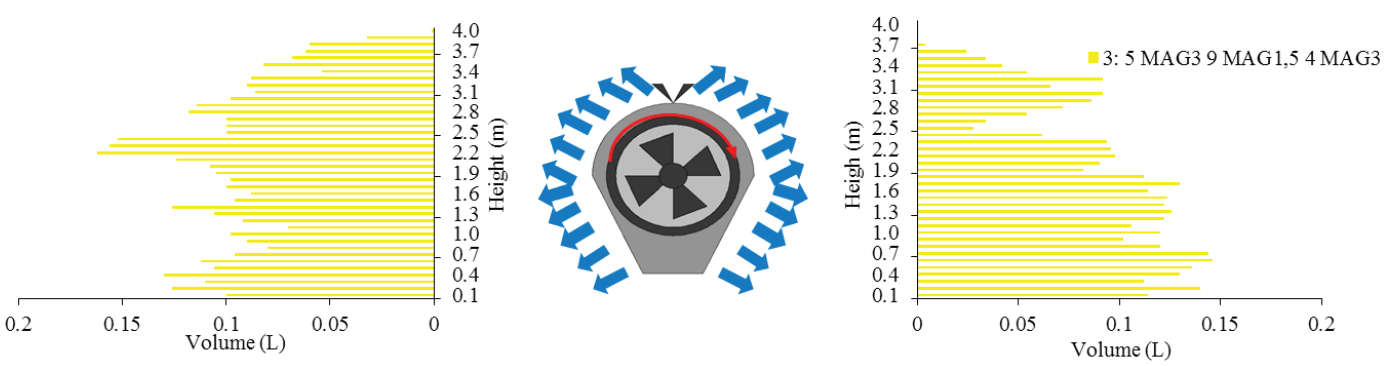

Figure 2. Vertical volumetric distribution from the axial fan sprayer on both sides of the spray arcs. 
descending rotation direction of the fan combined with the distance from the target. In other words, because of the higher airflow acting on the nozzles, especially number 4 to 11 (right side) (Figure 1), there was a greater liquid directing to the middle and lower portions of the vertical collecting bench (Figure 2). And coupled with this, because the nozzles in the higher portions of the spray were more distant from the vertical collecting bench, there was a lower spray deposition in the higher portions, contributing even more to a higher spray distribution variation on the right side.

In general, the $\mathrm{CV}$ of the vertical volumetric distribution values observed were $44 \%, 46 \%$ and $28 \%$, respectively for configurations 1,2 and 3 . These values were $68 \%, 66 \%$ and $79 \%$ lower than others previously reported in the literature, when working with a line of tubes fixed to a vertical post for collecting the sprayed liquid (Alvarenga et al. 2014). This difference may be due to the method for collecting the sprayed liquid, indicating that the best method to do so, in the case of an axial fan sprayer, is via a surface that covers all or part of the spray nozzle width.

Regarding the B. phoenicis control efficiency, it was observed that the period with the greatest reduction in the pest incidence was 14 DAA, $64 \%$ lower in relation to the control. It can also be observed that, even though configuration 3 provided more uniform distribution, when compared to

Table 3. Coefficient of variation ( $\mathrm{CV} \%)$ of the volumetric distribution provided by an axial fan sprayer, considering the side and two spray heights.

\begin{tabular}{lcc}
\hline \multirow{2}{*}{ Side } & \multicolumn{2}{c}{ Average collection height $(\mathrm{m})$} \\
\cline { 2 - 3 } & $0-1.6$ & $1.6-3.2$ \\
\hline Left & $28 \mathrm{bB}$ & $35 \mathrm{aB}$ \\
Right & $48 \mathrm{aA}$ & $46 \mathrm{aA}$
\end{tabular}

Means followed by the same lower-case letter in the line, or by the same upper-case letter in the column, do not differ by the Tukey test at $5 \%$. configuration 1 , there was no significant difference $(\mathrm{p}>0.05)$ on the $B$. phoenicis percentage incidence (Table 4). This shows that the use of higher flow rates at the ends of the arc results in more uniform spray distribution; and, although the droplets produced by these nozzles are larger, there was no reduction in the penetration capacity of the active ingredient in the canopy. This is probably due to the airflow and leaf density, which interfere on the B. phoenicis control in the inner and lower parts of the coffee canopy. The airflow has a direct influence on spray penetration in the canopy. Moreover, because the acaricide was applied at post-harvest, there was greater defoliation of the Arabica coffee plants (Da Matta et al. 2007), and therefore a lower barrier for penetration and spray deposition.

Analyzing the spray distribution on the plants, there was no significant difference $(p>0.05)$ between the nozzles configurations for the response variables of droplet density and percent coverage. However, there was a decrease in the percent coverage and droplet density from the upper to the lower positions of the canopy (Table 5). This is attributed to a greater overlap of branches in the upper canopy, if compared to the lower parts of the plants (Da Matta et al 2007). This results in an increase in leaf density and, therefore, reduces the penetration of the spray in the upper part of the canopy.

In the evaluation performed at $24 \mathrm{HAA}$, there was no significant difference $(p>0.05)$ of pest incidence, as a function of the applied spray volumes. This may indicate that the immediate effect of the active ingredient in question was low. Moreover, the maximum flow rate used may not have been sufficient, considering that the active ingredient requires high target coverage, since it acts by contact.

At 4 DAA, the flow rates of $200 \mathrm{~L} \mathrm{ha}^{-1}$ and $800 \mathrm{~L} \mathrm{ha}^{-1}$ reduced the incidence of $B$. phoenicis

Table 4. Percent incidence of Brevipalpus phoenicis verified after the application of acaricide with the axial fan sprayer configured with different spray nozzles.

\begin{tabular}{lccc}
\hline & $24 \mathrm{HAA}$ & $4 \mathrm{DAA}$ & $14 \mathrm{DAA}$ \\
\hline Control & $79 \mathrm{a}$ & $79 \mathrm{a}$ & $86 \mathrm{a}$ \\
Treatment & $54 \mathrm{~b}$ & $50 \mathrm{~b}$ & $31 \mathrm{~b}$ \\
\hline Configuration & & & \\
\hline $1: 18 \mathrm{MAG}_{1.5}$ nozzles & $55 \mathrm{a}$ & $51 \mathrm{a}$ & $29 \mathrm{a}$ \\
$3: 5 \mathrm{MAG}_{3}$ nozzles; $9 \mathrm{MAG}_{1.5}$ nozzles; $4 \mathrm{MAG}_{3}$ nozzles & $53 \mathrm{a}$ & $50 \mathrm{a}$ & $33 \mathrm{a}$ \\
\hline
\end{tabular}

Means followed by the same lower-case letter in the column do not differ by the Tukey test at $5 \%$. HAA: hours after application; DAA: days after application. 
by $42 \%$ and $57 \%$, when the droplet density was $190-525$ drops $\mathrm{cm}^{-2}$ and coverage was $4 \%$ and $16 \%$, respectively. For these flows and values of droplet density and percent coverage, at 14 DAA, $60 \%$ and $78 \%$ of pest incidence reductions were verified (Figure 3). Based on these data, an inverse relationship was observed between droplet density and coverage with pest incidence. Thus, it can be inferred that droplet density and coverage percentage should be considered as a basis for selecting the proper flow rate, especially when considering the reduced size of some targets, such as mite (Fernandes et al. 2010).

In the lower portions of the coffee plant, where the smaller droplet density and percent coverage are commonly deposited, the highest incidence of this pest was observed (Reis et al. 2000). Thus, it is important to increase the deposition in these places, because more droplets (drops $\mathrm{cm}^{-2}$ ) and increased coverage imply in greater and better distribution of the active ingredient, resulting in more effective control. This is especially true when using active ingredients that act by contact and ingestion.
However, new technologies that increase the droplet density and coverage by increasing spray volume may result in increased application costs and water consumption. Thus, a possible alternative would be to estimate the spray volumes needed to adequately cover a determined plant volume in a given canopy density condition. As observed in this study, adjustments of nozzle configuration can increase droplet density and canopy coverage, especially in the lower canopy portions of the coffee plants.

Considering the results obtained in the literature, to a $B$. phoenicis population of $85 \%$, a coverage of $\sim 40 \%$ is necessary (Fernandes et al. 2005). However, considering the maximum reduction of this plague obtained in the present study, which was $78 \%$, when employing a flow of $800 \mathrm{~L} \mathrm{ha}^{-1}$ (14 DAA), increasing the control to $87 \%$ would require a spray volume 2.5 times greater, applying the equations of incidence and percent coverage (Figure 3b). In other words, for a $9 \%$ increase in the control, an additional 1,200 $\mathrm{L} \mathrm{ha}^{-1}$ of the product are needed.

Table 5. Droplet density and percent coverage obtained in the upper, middle and lower portions of the coffee plant from an axial fan sprayer operating with different spray nozzle configurations.

\begin{tabular}{lcc}
\hline \multicolumn{1}{c}{ Configuration } & Droplet density $\left(\right.$ drops cm $\left.{ }^{-2}\right)$ & Percent coverage $(\%)$ \\
\hline $1: 18 \mathrm{MAG}_{1.5}$ nozzles & $370 \mathrm{a}$ & $10 \mathrm{a}$ \\
$3: 5 \mathrm{MAG}_{3}$ nozzles; 9 $\mathrm{MAG}_{1.5}$ nozzles; $4 \mathrm{MAG}_{3}$ nozzles & $344 \mathrm{a}$ & $8 \mathrm{a}$ \\
\hline Position in the canopy & & $13 \mathrm{a}$ \\
\hline Upper & $450 \mathrm{a}$ & $9 \mathrm{~b}$ \\
Middle & $361 \mathrm{~b}$ & $6 \mathrm{c}$ \\
Lower & $260 \mathrm{c}$ & \\
\hline
\end{tabular}

Means followed by the same lower-case letter in the column do not differ by the Tukey test at $5 \%$.
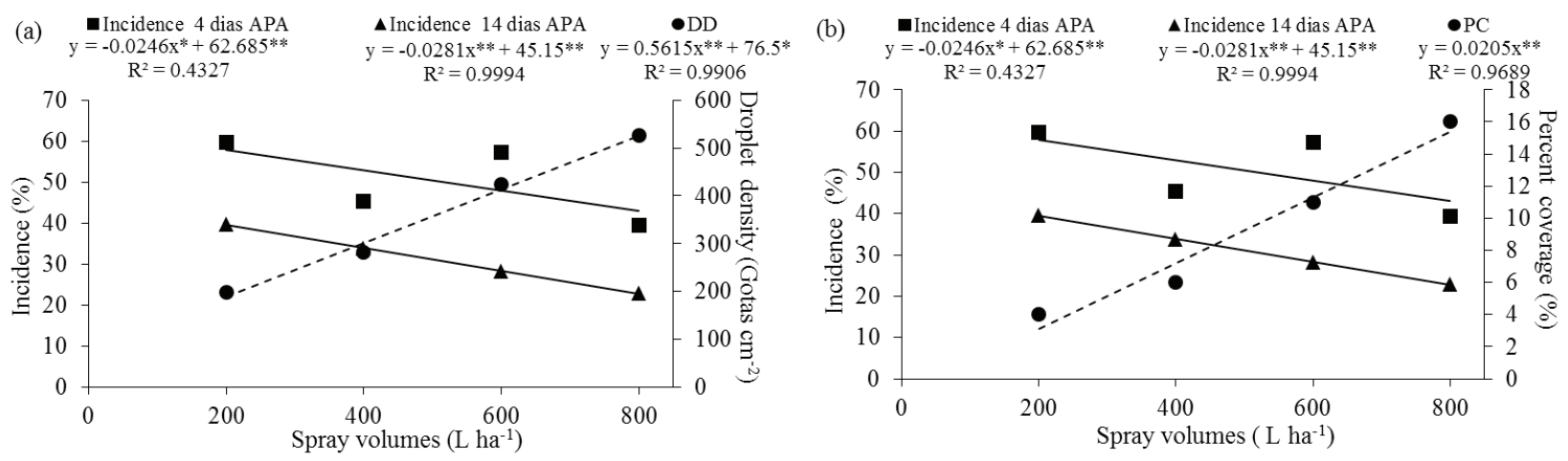

Figure 3. Incidence (\%) of Brevipalpus phoenicis observed at 4 and 14 days after the application of acaricide, in function of the droplet density (DD) (a) and percent coverage (PC) (b) resulting from the application of different spray volumes. * and ** Significant by the $t$ test at $5 \%$ and $1 \%$, respectively. 
Despite the fact that the increase in the uniformity of vertical volumetric distribution did not increase the $B$. phoenicis control efficiency, it was verified, in this study, that the use of spray nozzles which produce larger diameter droplets at the ends of the spray arc, as was the case of configuration 3, results in a more uniform spray distribution, with lower loss risks.

\section{CONCLUSIONS}

1. The use of spray nozzles with higher flow rates at the ends of the spray arc increases the vertical volumetric distribution uniformity of an axial fan sprayer.

2. The increased vertical volumetric distribution uniformity of an axial fan sprayer does not influence the $B$. phoenicis control efficiency.

3. The combination of nozzles with different flows on the spray arc does not hinder the $B$. phoenicis control in the inner parts of the coffee canopy.

4. The increase in droplet density and target coverage contribute to a greater B. phoenicis control.

\section{REFERENCES}

ALMEIDA, J. E. M. et al. Análise temporal e controle da mancha anular e do ácaro vetor do Coffee ringspot virus. Pesquisa Agropecuária Brasileira, v. 47, n. 7, p. 913-919, 2012.

ALVARENGA, C. B. et al. Air and liquid volumetric distribution in vertical in a hydro-pneumatic sprayer. Applied Research \& Agrotecnology, v. 7, n. 1, p. 71-79, 2014.

BALAN, M. G.; ABI SAAB, O. J. G.; SASAKI, E. H. Distribuição da calda na cultura da videira por turboatomizador com diferentes configurações de pontas. Ciência Rural, v. 36, n. 3, p. 731-38, 2006.

COMPANHIA NACIONAL DE ABASTECIMENTO (Conab). Acompanhamento da safra brasileira: produção agrícola de café. 2015. Available at: $<$ http://www.conab.gov. br/OlalaCMS/uploads/arquivos/15_09_30_11_17_06_ boletim_cafe_setembro_2015.pdf $>$. Acess on: 05 Nov. 2015.

CUNHA, J. P. A. R. et al. Deposição e deriva de calda fungicida aplicada em feijoeiro, em função de bico de pulverização e de volume de calda. Revista Brasileira de
Engenharia Agrícola e Ambiental, v. 9, n. 1, p. 133-138, 2005.

DA MATTA, F. M. et al. Ecophysiology of coffee growth and production. Brazilian Journal of Plant Physiology, v. 19, n. 4, p. 485-510, 2007.

FERNANDES, A. P.; FERREIRA, M. C.; MARTINELLI, N. M. Mortalidade do ácaro Brevipalpus phoenicis em função da cobertura de pulverização de acaricidas, com e sem adjuvantes, em mudas de café. Revista de Agricultura, v. 80, n. 2, p. 173-187, 2005.

FERNANDES, A. P.; FERREIRA, M. C.; OLIVEIRA, C. A. L. Eficiência de diferentes ramais de pulverização e volumes de calda no controle de Brevipalpus phoenicis na cultura do café. Revista Brasileira de Entomologia, v. 54, n. 1, p. 130-135, 2010.

GRAVENA, S. Manejo ecológico de pragas do cafeeiro. Jaboticabal: Cemip-Funep, 1992.

HERRERA PRAT, M. et al. Analisis de la velocidad del aire en la corriente de las asperjadoras utilizadas en frutales. Ciencias Técnicas Agropecuarias, v. 11, n. 2, p. 53-58, 2002.

HERRERA PRAT, M. I.; DE LA FIGAL, G. C; DE LA CUEVAS, H. M. Análisis de la aerodinámica del ventilador del pulverizador ASS-800 empleado en frutales. Ciencias Técnicas Agropecuarias, v. 22, n. 4, p. 15-19, 2013.

INSTITUTO NACIONAL DE TECNOLOGÍA AGROPECUARIA (INTA). $T \& C$ CIR: conteo y tipificación de impactos de pulverización. Versión 1.5. Buenos Aires: INTA, 2002.

MION, R. L. et al. Uso de mesa vertical como parâmetro para regulagens de turboatomizadores. Engenharia Agrícola, v. 31, n. 2, p. 352-358, 2011.

REIS, P. R. et al. Spatial distribution of Brevipalpus phoenicis (Geijskes) (Acari:Tenuipalpidae) in coffee plants (Coffea arabica L.). Anais da Sociedade Entomológica do Brasil, v. 29, n. 1, p. 177-183, 2000.

RODRIGUES, G. J. et al. Características do fluxo de ar de um pulverizador hidropneumático para aplicação de agroquímicos em plantas arbustivas. Engenharia na Agricultura, v. 16, n. 2, p. 199-207, 2008.

RUAS, R. A. A. et al. Proposta de método para a inspeção em pulverizadores hidropneumáticos. Coffee Science, v. 10, n. 1, p. 76-82, 2015.

SOTOLONGO, I.; HERRERA, M. Caracterización de la corriente de aire de una asperjadora de ventilador en el plano horizontal. Ciencias Técnicas Agropecuarias, v. 0, n. 1, p. 1-12, 1986. 